DOI:

Василь Туташинський, кандидат педагогічних наук, стариий науковий співробітник, Інституту педагогіки НАПН Украӥни

\title{
НАУКОВО-МЕТОДИЧНЕ ЗАБЕЗПЕЧЕННЯ ВАРІАТИВНОГО СКЛАДНИКА ЗМІСТУ ТЕХНОЛОГІЧНОЇ ОСВІТИ У ПРОФЕСІЙНОМУ ЛІЦЁ̈
}

У статті проаналізовано стан наукового-методичного забезпечення технологічної освіти учнів. Розкрито структуру педагогічної технології та зміст профільного навчання, а також особливості нових навчальних програм і підручників з предмета “Технологї”. На основі проведених фундаментального $i$ прикладного педагогічних досліджень обтрунтовано структуру варіативного складника технологічної освіти для професійного лічеюю.

Спроектовано $і$ на прикладі розроблених автором навчальноӥ програми $і$ посібника з технологій сучасного виробництва розкрито зміст варіативного складника профільної технологічної освіти учнів професійного ліцею. Особлива увага звертається на нову складову змісту технологічної освіти учнів - вивчення технологій 4.0 та соиіально-професійну орієнтацію молоді.

Ключові слова: технологічна освіта; науково-методичне забезпечення; навчальна програма; підручник; зміст загальної середньої освіти; варіативний компонент.

תim. 7.

Vasyl Tutashynskiy, Ph.D.(Pedagogy), Senior Researcher, Institute of Pedagogy of the NAPS of Ukraine

\section{SCIENTIFIC-METHODIC PROVIDING VARIATIONAL COMPONENT OF CONTENT OFTECHNOLOGICAL EDUCATION IN PROFESSIONAL LYCEUM}

The article analyzes the state of scientific and methodological provision of technological education of students. The pedagogical technology, a content of profile education, as well as features of new educational programs and textbooks on technologies are revealed. On the basis of the fundamental and applied pedagogical research the structure of the variable component of technological education for the professional lyceum was substantiated. The example of the author's developed training programs and manuals on the basics of machine science and technologies of modern production discloses the content of the profile technological education of students.

The scientific and methodological provision of technological education in the vocational school envisages the further development and implementation of the conceptual foundations of continuous technological education, the improvement of the content and methodology of teaching technology, the development of new educational and training programs, pedagogical software tools.

The content of the course "Technology of modern production" is proposed to be designed on the basis of the theory of technological developments and focus on the study of technologies 4.0.

The study of technologies, on the basis of which the fourth technological revolution begins, should ensure the competitiveness of young people in the labor market.

Keywords: technological education; scientific-methodical equipment; educational program; a schoolbook; contents of complete secondary education; variational component.

П остановка проблеми. Зміна завдань, структури і змісту загальної середньої освіти вимагають відповідного науково-методичного забезпечення навчального процесу. Саме проблема належного забезпечення навчального процесу, як показують проведені нами опитування, найбільше турбує вчителів. Яке ж наукове і навчально-методичне забезпечення необхідне новій українській школі? Які особливості забезпечення варіативного складника змісту освіти? Як вирішити проблему навчально-методичного забезпечення технологічної освіти у нових типах загальноосвітніх навчальних закладів, зокрема, у професійному ліцеї?

Мета статті - розкрити зміст науково-

методичного забезпечення варіативного складника технологічної освіти в професійному ліцеї.

У відповідності з визначеною метою задачами дослідження $€$ :

- проаналізувати стан проблеми науковометодичного забезпечення технологічної освіти в теорії та практиці;

- розкрити зміст нових освітніх програм, підручників і навчальних посібників з технологій;

- обгрунтувати структуру варіативного складника технологічної освіти професійного ліцею.

Аналіз останніх досліджень. У публікаціях результатів фундаментальних наукових досліджень 


\section{НАУКОВО-МЕТОДИЧНЕЗАБЕЗПЕЧЕННЯ ВАРІАТИВНОГОСКЛАДНИКАЗМІСТУ ТЕХНОЛОПЧНОӦОСВТТИ УПРОФЕСІЙНОМУ ЛІЦЁ̈}

[2; 3; 7] відображено концептуальні засади технологічної освіти та соціально-професійної орієнтації молоді. Проте, незважаючи на значні напрацювання з питань теорії і методики навчання з технологій, окремі автори (В. Доротюк, Н. Левченко, О. Марущенко, М. Піддячий, В. Стешенко, А. Тарара, В. Туташинський та ін. $[3,7]$ звертають увагу на недостатнє наукове обгрунтування сучасного змісту технологічної освіти, неповне відображення змістових ліній державного стандарту освітньої галузі “Технології” в програмах та навчальних посібниках, наявність дискримінаційного контенту в підручниках $[1,5]$, відсутність у змісті навчального предмета матеріалу, який забезпечує створення у навчальному закладі повноцінного середовища, сприятливого для свідомого і неупередженого вибору соціальної ролі та свого шляху, пов'язаного 3 трудовою діяльністю і вибором майбутньої професії $[4,7]$.

Проведені нами прикладні дослідження стану науково-методичного забезпечення технологічної освіти у різних типах закладів загальної середньої освіти (загальноосвітніх школах, академічних і професійних ліцеях, міжшкільних навчальновиробничих комбінатах) показують, що розроблені до 2018 року навчальні програми профільного навчання за спеціалізаціями технологічного профілю методичні та навчальні посібники з навчального предмета “Технології” не забезпечують достатній для конкуренції на ринку праці рівень підготовки молоді та не відповідають вимогам компетентнісного підходу в навчанні.

Зміст технологічної освіти учнів передбачає вивчення переважно технологій минулих століть. У змісті освіти недостатньо звертається увага на вивчення технологій сучасного виробництва та технологій майбутнього. У навчальних програмах загальноосвітніх і професійних закладів освіти практично не звертається увага на вивчення технологій 4.0. Вкрай обмеженим є навчальнометодичне забезпечення варіативного складника технологічної освіти.

Виклад основного матеріалу. Сучасний зміст освіти має задовольняти інтереси особистості, відображати соціально-економічні потреби і відповідати технологічному укладу розвитку суспільства. Викликом сучасності $€$ перехід людства до постіндустріального суспільства, та початок четвертої технологічної революції. Цей процес характеризується кардинальними змінами в економіці країни, попиті та пропозиціях на ринку товарів і послуг, відбувається під впливом стрімкого розвитку науки, освіти, техніки і цифрових технологій. У результаті зростає надання різноманітних послуг, докорінно змінюється структура виробництва та базові технології, змінюється й сама людина та ставлення до суспільних цінностей і якостей особистості.

У нових умовах соціально-економічного розвитку все важливішими стають уміння творчо мислити, швидко і критично опрацьовувати великі обсяги інформації, своєчасно приймати раціональні рішення, постійно підвищувати свій рівень компетентності та професіоналізм.

Зміни у соціальному замовленні зумовлюють зміни в цілях навчання та вимогах до якості освіти

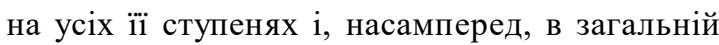
середній освіті.

Загальна середня освіта в Україні донедавна спрямовувалася на засвоєння учнями знань, формування вмінь і навичок, а фактично навчальний процес усе більше зводився лише до засвоєння знань та певних умінь. Школа недостатньо навчала учнів пошуку нової інформації, застосуванню навчального матеріалу на практиці, розвитку критичного і творчого мислення, формуванню вмінь вирішувати проблеми, самостійно приймати рішення, орієнтуватися на ринкупраці. Такий стан загальної середньої освіти пояснювався недосконалістю програм та підручників, вкрай обмеженими можливостями матеріально-технічного та інформаційного забезпечення шкіл, консерватизмом у освіті, їі відірваністю від вимог ринку праці.

Нині змінилися цілі і стратегія розвитку освіти, оновлено зміст загальноосвітньої підготовки учнів. Але, чи подолано ці проблеми тепер? Проведене нами анкетне опитування вчителів загальноосвітніх навчальних закладів різних типів (шкіл, ліцеїв, гімназій) показує, що вказані проблеми залишились актуальними. Понад 90 відсотків учителів технологій з 282 опитаних вважають незадовільним матеріально-технічне забезпечення навчального процесу. 72 відсотки вчителів технологій вказують на недостатнє забезпечення варіативного складника технологічної освіти, зокрема, на недосконалість навчальних програм, підручників та навчальних посібників, відсутність посібників для профільного навчання технологій.

Шляхами вирішення зазначених проблем $є$ узгодження змісту освіти з сучасними потребами суспільства, орієнтація навчальних програм, підручників на засвоєння учнями ключових i предметних компетентностей та застосування ефективних педагогічних технологій. Незважаючи на упровадження на рівні Державного стандарту базової і повної загальної середньої освіти особистісно зорієнтованого, компетентісного та 


\section{НАУКОВО-МЕТОДИЧНЕЗАБЕЗПЕЧЕННЯ ВАРІАТИВНОГОСКЛАДНИКАЗМІСТУ ТЕХНОЛОГІЧНОЇОСВІТИ УПРОФЕСІЙНОМУ ЛІЦЁ̈}

діяльнісного підходів у навчанні учнів, у навчальних програмах та підручниках поєднуються предметна система навчання 3 енциклопедичним підходом до структурування змісту освіти. Але якщо переважна більшість навчальних предметів транслюють знання 3 відповідних їм наук (мови - з лінгвістичних наук, природничі предмети - 3 наук про природу, суспільні дисципліни - 3 наук про людину і суспільство тощо), то трудове навчання і технології мають інтегрувати в собі знання та способи діяльності не тільки $з$ великого числа відповідних технічних наук (матеріалознавства, теорії різання, опору матеріалів, механіки, робототехніки, електротехніки, теплотехніки, гідравліки, технологій обробки матеріалів та багатьох інших), а й знайомити учнів із основами виробництва, підприємництва, маркетингу, менеджменту, сучасними технологіями, засобами праці різного рівня досконалості, питаннями культури і безпеки праці тощо. Значні можливості технологічної освіти для розвитку особистості учня, формування його творчих здібностей, технічного мислення, просторової уяви, підприємливості, працелюбства, формування умінь, удосконалення психофізіологічних якостей учнів.

Відповідно до Державного стандарту базової та повної загальної середньої освіти метою освітньої галузі “Технології” $€$ формування і розвиток проектно-технологічної та інформаційнокомунікаційної компетентності для реалізації творчого потенціалу учнів і їх соціалізації у суспільстві.

Завдання технологічної освіти передбачають не тільки формування уявлень, але й засвоєння вмінь, застосування знань, набуття певного досвіду, формування загальнолюдських цінностей. Основною умовою реалізації технологічного компонента змісту освіти є технологічна та інформаційна діяльність, що провадиться від появи творчого задуму до реалізації його в готовому продукті.

Аналіз концепцій та систем трудового навчання, а також експериментальна апробація нового змісту, методів і засобів технологічної освіти показують, що іiї сучасні завдання можливо вирішити на основі проектної технології навчання.

У структуру розробленої нами проектної

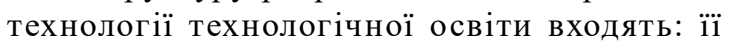
концептуальна основа; мета навчання; зміст навчального матеріалу та його організаційне забезпечення; форми і методи спільної діяльності вчителя і учнів, засоби навчання і професійного орієнтації учнів, а також діагностика результатів навчального процесу педагогом та їх рефлексія учнем.

Проектна педагогічна технологія стосовно учня - це діяльність, спрямована на розв'язання значущої проблеми, сформульованої у вигляді мети і завдань проекту, а іiі результатом $є$ знайдений ним спосіб розв'язання проблеми, що має практичний характер і прикладне значення. Проектна педагогічна технологія надає можливість виявити себе, проявити свої здібності, застосувати знання, випробувати свої сили у певному виді майбутньої професійної діяльності, принести користь і публічно показати результат роботи як розроблений і реалізований проект.

Вчитель, застосовуючи проектну технологію, вчить учнів: бачити та формулювати проблему; визначати мету і задачі, які випливають 3 виявленої проблеми; шукати та виокремлювати потрібну інформацію; проводити необхідні дослідження; здійснювати добір доцільних технологічних процесів для створення продукту проектування; планувати навчальний процес; аналізувати успішність проектної діяльності та презентувати їі результати.

3 2018/2019 навчального року предмет “Технології” вивчається учнями як обов'язкововибірковий предмет за новими програмами і підручниками, розробленими відповідно до концепції "Нова українська школа".

Нова навчальна програма “Технології”, затверджена наказом МОН України від 23.10.2017 p. №1407, спрямована на формування ключових та предметної проектно-технологічної компетентності й складається 3 таких десяти обов'язкововибіркових навчальних модулів: І. Дизайн предметів інтер'єру; II. Техніки декоративноужиткового мистецтва; III. Основи підприємницької діяльності; IV. Креслення; V. Комп'ютерне проектування; VI. Основи автоматики і робототехніки; VII. Дизайн сучасного одягу; VIII. Ландшафтний дизайн; IX. Краса та здоров'я; Х. Кулінарія.

Детально зміст усіх модулів навчальної програми розкрито у новому підручнику “Технологіï” [6].

3 указаних десяти навчальних модулів можна обрати лише три. Але вивчення предмета “Технології” можна доповнювати профільними предметами, спецкурсами та факультативами. При цьому зміст навчання необхідно розглядати в єдності інваріантної та варіативної складових навчального плану.

Особливістю технологічної освіти у професійному ліцеї є диференціація тї змісту, пов'язана $з$ формуванням професійних намірів, 


\section{НАУКОВО-МЕТОДИЧНЕЗАБЕЗПЕЧЕННЯВАРІАТИВНОГОСКЛАДНИКАЗМІСТУ ТЕХНОЛОПЧНОЇОСВІТИ УПРОФЕСІЙНОМУ ЛІЦЁ̈}

створенням умов для професійного і соціального самовизначення, професійною підготовкою за робітничими професіями, вивченням сучасних технологій у обраній галузі виробництва, реалізацією творчого потенціалу учнів у процесі технологічної діяльності.

У професійномуліцеї за допомогою варіативного складника змісту освіти забезпечується поглиблений рівень технологічної освіти, всебічне ознайомлення 3 професією, що відповідає індивідуальним можливостям учня; формування в учнів здатності мобілізувати свої творчі можливості у обраному виді трудової діяльності.

Технологічна освіта учнів ліцею повинна здійснюватися за обраним профілем. Педагогічна доцільність профільної технологічної освіти у професійному ліцеї визначається:

- наявністю в учнів ліцею інтересів і професійних намірів щодо певних видів трудової діяльності та потребою підготувати їх до свідомого вибору майбутньої професії;

- потребами ринку праці у кваліфікованих спеціалістах;

- запитами і вимогами, що висувають роботодавці до підготовки випускників закладів освіти.

Профільне навчання технологій у професійному ліцеї має надавати можливості для рівного доступу до якісної освіти впродовж усього життя, формувати особистість, здатну до самореалізації, професійного зростання й мобільності. У зв'язку 3 цим зміст варіативного складника профільної технологічної освіти має відповідати не лише державним освітнім стандартам і науковопедагогічним вимогам, а й запитам роботодавців.

Відповідно до зазначених вимог нами розроблено нові навчальні програми і посібники для професійного ліцею з основ машинознавства та з технологій сучасного виробництва, а також здійснюється розроблення і апробація контенту для електронних програмних засобів навчання. Зміст навчання у професійному ліцеї передбачає ознайомлення учнів із сучасними машинами $\mathrm{i}$ технічними системами, формування компетентності 3 технологій у пріоритетних для інноваційного розвитку України галузях виробництва (енергозберігаючі технології, технології аграрного виробництва, технології літакобудування та суднобудування, ракето-космічні технології). Особлива увага звертається на вивчення технологій 4.0 (інтернет речей, технології 3-D друку, нанотехнології та ін.) Вивчення сучасних виробничих технологій здійснюється у процесі виконання учнями індивідуальних та колективних проектів.
Висновки та перспективи подальших розвідок. Науково-методичне забезпечення технологічної освіти у професійному ліцеї передбачає упровадження нового змісту навчання технологій 4.0, розроблення нових освітніх та навчальних програм, створення на засадах компетентністного підходу підручників, навчальних та методичних посібників, педагогічних програмних засобів.

Подальші розвідки проблеми мають спрямовуватися на створення нового покоління засобів навчання сучасних технологій.

\section{ЛІТЕРАТУРА}

1. Марущенко О.Л. Трудове навчання в школі: гендерний аналіз. Трудова підготовка в сучасній школі. 2012. № 6. C. $28-30$.

2. Сидоренко В.К., Коберник О.М. Концепція технологічної освіти учнів загальноосвітніх закладів України (проект). Трудова підготовка в закладах освіти. 2010. № 6 .

3. Піддячий М. “Освіта і наука України у вимірі громадянських суспільств: соціально-професійна орієнтація", Неперервна професійна освіта : теорія і практика. Пед. науки, вип. 3-4 (48-49), С. 59-65, 2016.

4. Піддячий М. “Освіта і наука України : соціальнотрудовий розвиток молоді”, Науковий часопис Національного педагогічного університету імені М. П. Драгоманова. Серія 13 : Проблеми трудової та професійної підготовки, вип. 8, с. 75-80, 2017.

5. Тарара А. М. Методологічні аспекти проектування змісту профільного навчання технологій у старшій школі. Проблеми сучасного підручника: зб. наук. 217 праць / ред. кол.; голов. ред. - О. М. Топузов. К. : Педагогічна думка, 2016. Вип. 16. С. 403-414.

6. Туташинський В.І., Кірютченкова I.В. Технології. 10 (11) кл. - К.: Педагогічна думка. $-2018 .-228$ с.

7. Ассанов, М. О. Васьківський, М. В. Доротюк В. І. та ін. Формування освітнього середовища профільної школи: монографія - Нац. акад. пед. наук України, Ін-т педагогіки. К.: Педагогічна думка, 2013. 200 с.

\section{REFERENCES}

1. Marushchenko, O.L. (2012). Trudove navchannya v shkoli: hendernyy analiz [Labor training at school: gender analysis]. Labor training in a modern school. No. 6, pp.2830. [in Ukrainian].

2. Sydorenko, V.K. \& Kobernyk, O.M. (2010). Kontseptsiya tekhnolohichnoyi osvity uchniv zahalnoosvitnikh zakladiv Ukrayiny (proekt) [The concept of technological education of students of general educational institutions of Ukraine (a project)]. Labor training in educational institutions. No. 6, pp.3-5. [in Ukrainian].

3. Piddyachyy, M. (2016). "Osvita i nauka Ukrayiny u vymiri hromadyanskykh suspilstv: sotsialno-profesiyna oriyentatsiya" ["Education and science of Ukraine in the dimension of civil society: the social and professional orientation"]. Continuing Professional Education: 


\section{АНАЛІЗ НАВЧАЛЬНОГО ПЛАНУ ПІДГОТОВКИ ЗДОБУВАЧІВ ВИЩОЇ ОСВІТИ ДРУГОГО (МАГІСТЕРСЬКОГО) РІВНЯ ГУМАНІТАРНОГО НАПРЯМКУ}

Theory and Practice. Pedagogical science, Vol. 3-4 (4849), pp. 59-65.[in Ukrainian].

4. Piddyachyy, M. (2017). "Osvita i nauka Ukrayiny sotsialno-trudovyy rozvytok molodi"["Education and science of Ukraine: the social and labor development of youth"]. Scientific journal of the National Pedagogical University named after M.P. Drahomanov. Series 13: Problems of Labor and Vocational Training. Vol. 8, pp. 75-80. [in Ukrainian].

5. Tarara, A. M. (2016). Metodolohichni aspekty proektuvannia zmistu profilnoho navchannia tekhnolohii u starshii shkoli [The Methodological aspects of designing the content of profile education of technology in high school]. The problems of the modern textbook: a collection of 217 scientific works. (Ed.). O. M. Topuzov. Kyiv: Pedahohichna dumka, Vol. 16, pp. 403 - 414. [in Ukrainian].

6. Tutashynskyy, V.I. \& Kiryutchenkova, I.V. (2018). Tekhnolohiyi. 10 (11) kl. [Technologies. 10 (11) cl.]. Kyiv: Pedahohichna dumka, 228 p. [in Ukrainian].

7. Assanov, M. O., Vaskivskyy, M. V., Dorotyuk, V. I. et al. (2013). Formuvannya osvitnoho seredovyshcha profilnoyi shkoly: Monohrafiya [The formation of the educational environment of the profile school: a monograph]. Kyiv: Pedahohichna dumka, 200 p. [in Ukrainian].

Стаття надійшла до редакції 08.02.2019

УДК [378.091.214:8]:005.52

DOI:

Сергій Шаров, кандидат педагогічних наук, доиент кафедри української $і$ зарубіжної літератури

Мелітопольського державного педагогічного університету імені Богдана Хмельницького

\section{АНАЛІЗ НАВЧАЛЬНОГО ПЛАНУ ПДГОТОВКИ ЗДОБУВАЧІВ ВИЩОЇ ОСВІТИ ДРУГОГО (МАГІСТЕРСЬКОГО) РІВНЯ ГУМАНІТАРНОГО НАПРЯМКУ}

У статті аналізується навчальний план підготовки здобувачів вищої освіти другого (магістерського) рівня спеціальності 014.01 Середня освіта. Украӥнська мова і література. Навчання магістрів передбачає иілеспрямований та багатофункиіональний проиес, який має специфічну мету, форми та методи. Визначено дисципліни, які відносяться до ичиклів загальної, професійної підготовки, а також ичклувибіркових дисциплін. Розглянуто перелік загальних та фахових компетентностей, проаналізовано результати навчання, які свідчать про ступінь сформованості компетентностей у межах обраної спеціальності.

Ключові слова: здобувач вищої освіти; підготовка магістрів; украӥнська мова і література; вища школа; навчальний план; освітня програма.

Jim. 11.

Serhiy Sharov, Ph.D.(Pedagogy), Associate Professor of the Ukrainian and Foreign Literature Department Melitopol Bohdan Khmelnytskiy State Pedagogical University

\section{ANANALYSIS OFTHE CURRICULUM FOR THE PREPARATION OF CANDIDATES FOR HIGHER EDUCATION OFTHE SECOND (MASTER'S) LEVEL OFTHE HUMANITIES}

The article focuses on the analysis of the curriculum for the preparation of candidates for higher education of the second (master) level of specialty 014.01 Secondary education. Ukrainian language and literature. The applicants can enter the second (master) level on the basis of the educational degree "Bachelor" or the educational qualification level "Specialist". Master training provides for a focused and multifunctional process of preparing competitive specialists who have a specific goal, forms and methods. The main forms of organization of education for applicants of higher education of the second (master's) level include lectures, practical, seminar classes, independent educational activities of students. One of the ways to modernize the content of education with a competence-based approach is to update the educational programs and curricula for the preparation of a competitive applicant for higher education. It is noted that the preparation of masters is based on several regulatory documents of the specialty, namely the educational profile of the specialty, the educational program of the specialty, the curriculum of the specialty. It is noted that applicants for higher education of the second (master) level of this specialty are studying according to the educational and professional program, which is called "Secondary education. Ukrainian language and literature. English language and literature, fields of knowledge 01 Education / Pedagogy". It is revealed that in the curriculum there are disciplines related to the cycles of general professional training, as well as cycles of selective disciplines. The process of training in the magistracy should be aimed at the formation of students " general cultural and professional competencies, provided for by the educational standards. The article describes the competencies that a student acquires during studying at the magistracy. It is noted that the educational program contains only one integral competence, but a significant number of general and professional competencies that are 